\title{
Textos de ficção e tradição cientificista - ficções da cultura histórica
}

\author{
Bruno Flávio Lontra Fagundes*
}

\begin{abstract}
Resumo. Este artigo aponta alguns dilemas e desafios colocados ao trabalho do historiador, hoje, pela longa tradição histórica cientificista herdada do século XIX, que colocou a História e a Literatura em campos disciplinares rigorosamente separados. Através da análise dos procedimentos de composição e criação literária de João Guimarães Rosa em seu livro Grande Sertão: Veredas, este artigo procura argumentar em torno do valor de textos literários como textos que podem ajudar os historiadores na suplantação daqueles dilemas e desafios.
\end{abstract}

Palavras-chave: Tradição histórica. Conhecimento histórico. Literatura.

Não há unanimidade entre os historiadores quanto a se confiar nos textos ficcionais como fonte histórica. Alguns os rejeitam, ora porque questionam o texto ficcional como informação verídica, ou verificável, sobre as realidades de fato, ora porque recusam o texto ficcional como impertinência de base à própria disciplina histórica, argumentando que os textos ficcionais são "coisa da Literatura". Este artigo assinala alguns aspectos de uma tradição historiadora de longa data, e pontua como nesta se engatam os termos de certo tipo de relação entre História e Literatura, com duas conseqüências:

* Mestre em Teoria da Literatura e Doutorando em História na UFMG.

Anos 90, Porto Alegre, v. 14, n. 25, p.175-197, jul. 2007 
Textos de ficção e tradição cientificista ficções da cultura histórica

a que barra os textos ficcionais como fontes históricas, e a que estabelece a certeza de que o texto do historiador é estritamente a expressão de realidades que só se manifestam no texto, nunca constituidas pelo texto. Os textos aparentados com o ficcional seriam tanto da Literatura que o historiador mesmo deve fugir da aparência de ficcional em seu próprio texto, como se ele pudesse fazer isso por simples escolha de método. A literatura de João Guimarães Rosa glosa essa tradição para fazer sua ficção, e por isso será tocada aqui ao final: um escritor de ficção pode contribuir para o historiador lidar com alguns de seus dilemas teórico-conceituais e com as incertezas de suas práticas investigativas. Por que não?

\section{Considerações críticas sobre a constituição e permanência de uma tradição}

Uma história da História que analisa a constituição da ciência histórica no século XIX identifica o fundo comum da Retórica Clássica a que pertenciam o que se chamou, depois, "textos históricos" e "textos literários". Ambos os textos sempre foram uma só coisa: pertenciam ao campo das considerações sobre o sentido e a ordem dos seres e das coisas no universo. A pretensão de se constituir um lugar que pudesse oferecer guarida aos medos de uma Europa convulsionada por revoluções sociais e profundamente modificada pelos avanços do progresso técnico foi a motivação para a criação de uma ciência que fornecesse alguma segurança para o futuro. Esse movimento divide radicalmente a Retórica, de onde surgem a História e a Literatura, o que termina por fixar dois campos disciplinares antípodas. Os criadores da Ciência Histórica do século XIX se separam, então, de algo que seria seu impróprio, seu oposto, a Literatura, e disciplinarizam cientificamente o conhecimento do passado. Hayden White faz o histórico desse processo com algum detalhamento (White, 1994 a e 1994 b).

Anos 90, Porto Alegre, v. 14, n. 25, p.175-197, jul. 2007 
Através dessa separação disciplinar, a História passou a se referir ao real, ao que estaria fora da construção textual do cientista, o verificado pelo acesso do documento de onde se extrairia o fato histórico. O documento onde estão registrados os fatos passou a ser chancela de realidade, e como a Ciência Histórica se constituía como um campo cujo lastro eram os arquivos, ela passou a ser aquilo pelo qual se falava a realidade, e o historiador passou a ser o agente que recolhe a realidade pelo acesso aos documentos. Nessa separação, igualmente se fixou o que seria a Literatura: construção textual, reino da imaginação fantasiosa ao qual o documento não acessa e da qual não há registro, e igualada à ilusão. Dentro dessa tradição que se constituía - e é dentro dela que assim entendemos deve ser compreendida - aparecia a ficção, um termo que marca o específico do objeto da Literatura, e a qual passou a ser associada ao irreal, o que só tem existência dentro da mente, e a equivaler a tudo que não fosse história e realidade. Nesse processo, ficava expurgado da Ciência Histórica tudo que se parecesse com o imaginativo, o inventado.

H. White vai além desse ponto, e a fecundidade de seu ensaio está na formulação conseqüente: a diferença quanto à versão retórica não se concretizaria se o historiador não praticasse certas "exclusões estilísticas"; o que tinha implicações para o tipo de eventos que podiam ser representados em uma narrativa. É excluída a espécie de eventos tradicionalmente concebida como matéria da crença e do ritual religiosos (milagres, acontecimentos mágicos ou divinos), por um lado, e a espécie de eventos "grotescos", que são o tema da farsa, da sátira e da calúnia, por outro. Acima de tudo, essas duas ordens de exclusão consignam ao pensamento histórico a espécie de eventos que se presta ao entendimento do que quer que correntemente passe pelo senso comum educado. Elas efetuam uma disciplinação da imaginação [...]. (Costa Lima, 1989, p. 69, grifos do autor). 
Textos de ficção e tradição cientificista ficções da cultura histórica

É de se salientar, ainda, um tema de profundas conseqüências no interior dessa tradição que se constituía: o de que a História passou a equivaler à verdade porque fundada na idéia de que o real é o que existe de fato, atestado pelos documentos. Ao historiador cabia o adequado manejo das fontes, para que, metodicamente recolhendo os fatos do real nos documentos, revelasse a verdade contida dos fatos, de cuja certeza ele era mero recolhedor. Instituiu-se uma certeza: a de que, se está no documento, o que existe é a verdade! A verdade historiadora estaria antes do texto, nos protocolos partilhados socialmente sobre onde se procurar a verdade com maior possibilidade de encontrá-la, o que a ciência histórica reitera como valor. Há quem assegure que o acento que a Ciência da História passará a conferir sobre a questão das fontes documentais reprimirá a discussão sobre o texto historiador e sobre a natureza da compreensão histórica, já que ao historiador bastava encontrar a realidade das coisas inscrita nos documentos. Espécie de avalista da verdade, seu texto não podia ser interferente, e tudo que fosse construção seria próprio do ficcional, fantasia falseadora e imaginação especulativa motivadoras de outros critérios de análise: a crítica de Literatura.

O modelo característico das ciências que têm como certo que seus objetos estão completamente fora do homem e alheios às suas vicissitudes era o que impregnava a nascente Ciência Histórica da época das certezas de uma era de progresso e exatidão técnicos. Iser sugere uma pequena consideração, porém, que subverte algumas das "certezas irrefletidas" (expressão do autor) dessa tradição, qual seja, a de que o problema do real e do ficcional também atormentou a teoria do conhecimento desde o início da idade moderna: "como pode existir algo que, embora existente, não possui o caráter de realidade?" (Iser, 1996, p. 14). Como pode ser real uma coisa que sabemos que existe mas que não podemos afirmar sua condição de realidade de fato fora da mente e do texto? As conseqüências dessa tradição não são nada insignificantes, e veremos ao final como ela repercute na obra literária de João Guimarães Rosa.

Anos 90, Porto Alegre, v. 14, n. 25, p.175-197, jul. 2007 
O passado não se reduz à mera recordação de sociedade cuja história está inscrita na massa de documentos. Foucault ajuda-nos aqui: a memória é a forma de uma sociedade conferir status à massa documental da qual não se aparta, e a história é memória porque os historiadores são a sociedade assegurando que temos memória, dignificando seu passado, conferindo status aos documentos histó-ricos da sociedade ao tomá-los como fontes. Nesse sentido, a memória vem antes da história, e o historiador reincide na função de certificar a sociedade de que ela tem história ao manusear e escrever o passado a partir dos documentos que a sociedade guardou recolhidos em arquivos.

O historiador torna-se alguém que institui, pela operação historiográfica, a memória em que se inscreve uma sociedade toda. É nessa chave de leitura que vamos aqui: o que é a literatura, os textos ficcionais, senão documentos, coisas de sentido que emprestam à sociedade suas pautas de compreensão do que lhe cerca, seus atos e comportamentos? E o que são os textos dos historiadores senão conferência de sentido, produtos textuais sobre a sociedade, fontes primárias também, para seguir com White? Estamos com Costa Lima a respeito do fato de que o ficcional não é uma operação arbitrária, que confunde, mas uma operação impositiva que manifesta um diálogo entre autor e leitor, ou assim também não é o que faz o historiador, cujos textos também são recepcionados? Pretendemos que a ficção da literatura possa ser documento, sim, mas um documento de algo que não é o que a análise sociológica da literatura faz numa chave reflexológica da relação literatura-sociedade.

Insistamos, pois: a abrangência das ficções resulta de que, no mundo humano, o sentido das coisas, do mundo e da vida é sempre algo a elas imposto. Essa imposição não se confunde com a pura arbitrariedade, pois a movência das ficções as torna sempre capazes de estabelecer uma relação dialógica com a realidade que tornam significativa. Quando se rompe esse diálogo, a ficção adquire a rigidez do mito, cujo limite é o dogma [...] (Costa Lima, 1989, p. 77). 
Textos de ficção e tradição cientificista ficções da cultura histórica

Nessa perspectiva, que não toma a literatura como falseamento ou devaneio, locus da ficção, o historiador tem a oferecer o que o escritor literário tem a oferecer: versões, leituras sobre o real consumadas no extenso patrimônio de textos de história e de literatura que as sociedades guardam como seus. Nessa perspectiva ainda, é uma ficção imaginar que o ficcional falseia o real.

Fonte histórica para o historiador, o texto ficcional se justifica. Qualquer organização de dados num relato que comunica uma realidade não escapa dos processos de linguagem criadores de significado; porém, nem tudo que deriva dele é absolutamente opaco a ponto de não podermos afirmar realidade alguma a partir dos textos literários. Hayden White e Wolfgang Iser já alertaram sobre a medida de realidade que envolve os dispositivos representacionais em Literatura. Ao afirmar que o conhecimento historiográfico não diminui porque os historiadores conferem sentido a suas narrativas da mesma maneira que escritores de ficção, White alega que assim só o seria se "acreditássemos que a literatura não nos ensinou algo acerca da realidade, por ter sido o produto de uma imaginação que não era deste mundo, mas de outro, de um mundo inumano [...]" (White, 2001, p. 115).

Já Iser adverte-nos de que nem tudo no texto ficcional é fictício, visto que "há no texto ficcional muita realidade que não só deve ser identificável como realidade social, mas que também pode ser de ordem sentimental e emocional" (Iser, 1996, p. 14). Estratégias e arranjos do universo das relações no real podem ser observados pelo modo como a literatura representa ficcionalmente a realidade vivida; ao representar a realidade no texto, o ardil literário fornece esquemas persuasivos de interpretação dos processos sociais como construídos no discurso ficcional, de modo a sugerir o conjunto de percepções e valorações de que lançam mão os agentes reais da vida fora do texto apreendidos na figura dos personagens fictícios da vida ficcionada do texto.

Porém, nada mais razoável do que o historiador tomar o texto literário com cautela. O problema não é esse, e sim o fato de se evitar o texto literário como fonte historiadora, o que parece-nos ainda vestígio 
da tradição cientificista do século XIX, que separou História de Literatura com tanta certeza, expurgando de seu universo de concepções a idéia de que a ficção de alguma forma informa-nos do real. Por repartição disciplinária, certos textos seriam "da Literatura" e outros "da História", embora Hayden White nos pergunte sobre o que, textualmente, faz de um texto um texto "especificamente histórico" ou "especificamente literário". Veja-se, a respeito, como José Murilo de Carvalho apresenta a análise de Heloiza Starling sobre o Grande Sertão: Veredas:

[...] Pode [o livro] ser lido como uma alegoria política do Brasil? Ruminando o livro, Heloiza Starling descobriu essa vereda e segue por ela num empreendimento que tanto tem de fascinante quanto de temerário. É fascinante a nova dimensão que explora, é temerária a tentativa de ler politicamente um texto de ficção. Parte do fascínio, aliás, talvez esteja na temeridade. (Starling, 1999, s.p.).

Com certeza, nisso tudo há uma forte tradição de cultura histórica - na qual, talvez sem perceber, estão alguns historiadores, reiterando-a quando deviam indagar sobre ela - tradição em que vicejam duas certezas cristalizadas: a de que a história é produtora de verdades porque é o oposto do ficcional que equivale ao fantasioso e ao imaginado, e a de que a produção de verdades da História exige uma forma de verbalização, de colocação de dados recolhidos de pesquisa em arranjo textual de linguagem específico, com o qual se identifica a ciência. Essa cultura histórica reconhece a verdade não só a partir das referências aos fatos testificados pelo documento de arquivo, que seriam a verificação do real, mas ainda por uma forma textual com a qual se identificam as verdades que a instituição científica teria a nos oferecer. Isso tudo foi forjando a convicção de que o texto do historiador é qualquer coisa, desde que não traga qualquer das marcas que identificam a forma do texto ficcional, porque a verdade da história estaria fora dos textos, para além da construção que eles podem fazer da realidade. 
Textos de ficção e tradição cientificista ficções da cultura histórica

\section{Considerações sobre narrativa histórica e ficção, e o desdobramento relativista}

Benjamim afirmava que o principal historiador é o homem velho que conta estórias, e isso parece-nos um emblema da retomada da natureza narrativa da história na seara historiadora, na esteira do que se inaugura a discussão quanto à pertinência do texto ficcional como fonte para o historiador e as semelhanças de seu texto com operações que regem a construção dos textos ficcionais. Não faremos aqui uma vasta apreciação acerca desse retorno - que para alguns não é um retorno, porque nunca houve partida -, mas é possível apanhar alguns itens marcantes da discussão que colocam autores em campos antagônicos. Qualquer que seja o momento identificado como o da retomada, no debate dos historiadores, da questão da natureza narrativa da História, ele se tem nutrido da pergunta de De Certeau (1992b) sobre o que fazem historiadores quando fazem história. O primeiro item que assinala divisões no debate é que muitos postulam que o que os historiadores fazem é escrever textos simplesmente, pactuando com os escritores ficcionais operações de conferência de sentido às realidades do passado, organizadas a partir de dados descobertos de pesquisa. Hayden White é um dos defensores dessa posição. Segundo ele, os historiadores vão à cultura literária ficcional herdada de sua época buscar os plots com que arranjam a realidade em enunciados inteligíveis por um jogo de identificação entre texto historiador e leitor.

Tomado como um autor que iguala a história à ficção, White é o inimigo teórico principal de todos os que rejeitam a afirmativa de que a História faz apenas textos que se legitimam pela chancela dos arquivos onde encontramos o passado. Do outro lado da trincheira teórica, esses autores não se conformam com a igualação da História à Ficção, embora concordem com o fato de que a História preencha vazios e lacunas do passado pelo texto, porque a pesquisa não consegue alcançar o que seria o passado completo, íntegro. A 
maior crítica a White provém do fato de que, fazendo aquela igualação acima referida, cairíamos num absoluto relativismo, em que alguma coisa quer estar em nenhum lugar e em todo lugar ao mesmo tempo, situação em que a verdade, sempre movente, seria impossível de ser alcançada. Não vamos entrar na discussão de De Certeau, que justifica os resultados textuais do ofício historiador por sua localização num lugar institucional de disciplina científica porque não concordamos que o texto do historiador se explique por seu lugar de prática, apenas. Além do mais, não partilhamos da idéia de que a história se restrinja ao lugar acadêmico, haja vista que, como cultura histórica, a história está em outros lugares dos quais recebem injunções pelas quais o campo é conformado. A cultura histórica dos historiadores troca muito de seus termos com a cultura histórica da sociedade como um todo.

Parece-nos, no entanto, que há uma primeira nota de esclarecimento a se fazer: entre texto narrativo e texto argumentativo. Nós não só entendemos e/ou compreendemos o que se nos diz através de modelos de texto do qual se sabe, no início, o fim a que se quer chegar, ao qual vamos sendo encaminhados lendo e/ou ouvindo a demonstração argumentativa que reforça o que já sabemos desde o princípio. Esse é um modelo que conta com a autoridade da ciência, que lhe confere o status de um saber autorizado. De outro modo, o texto narrativo - o do homem velho de Benjamin - recolhe sua autoridade de saber autorizado da antigüidade que o tempo vivido confere aos homens que viveram, em que saber se faz sabedoria. A antinomia forma científica de texto-saber e forma narrada de textosabedoria não cabe!

Porque uma narração também é explicativa, mas seu modo de exposição é outro: numa narração seguimos uma estória, e onde vamos chegar não está dito no início, e a valoração do que queremos transmitir não se faz por argumentos, mas pelo realce, desprezo, seleção, valorização dos dados do passado que vão sendo arranjados na estória por aquele que conta, com o que também percebemos 
Textos de ficção e tradição cientificista fiç̧ões da cultura histórica

tomadas de posição e posturas diante dos fatos. Ricoeur (1994) fala-nos de uma "inteligência narrativa". Porém, há uma diferença importante entre a exposição argumentativa e a narrativa que Araújo (1992) ajuda-nos a perceber: na exposição por narração, o contador de estórias não precisa prestar contas de seu lugar e não vive a exigência de expor seus modelos, enquanto o argumentador vive a exigência de informar em que base de apoio se funda o que vai dizer. Mas não tenhamos ilusões: ambos valoram, arranjam acontecimentos do passado segundo raciocínios e lógicas de compreensão e exposição.

A discussão que retorna ao campo do historiador sobre a natureza narrativa de sua exposição esbarra nesse impedimento de base que, parece-nos, registra um resquício cientificista de que o narrador e a narração não explicam e não constituem saber; os modelos científicos que seriam próprios da Ciência Histórica exigiriam o esclarecimento que se vai revelando por argumentação e demonstração, impróprios das articulações narrativas. Se a narrativa é o modo mais elementar e antigo de o homem se comunicar, de o homem se comunizar ao compartilhar estórias, não seria uma tarefa historiadora encontrar na narração um modo de se reaproximar de suas comunidades pelo convívio das estórias que são contadas, sem temer que elas sejam neutras ou não informem sobre as realidades vividas? Reis (2005) organiza o argumento de Paul Ricoeur, segundo o qual quem a História, faz narrativas, mas de um modo especial, realizando a temporalidade própria do tempo histórico.

Ricoeur considera que entre tempo vivido - experiência, passagem dos tempos, idade, medida do movimento dos corpos no percurso da existência - e tempo cósmico da alma, só há aporia: é impossível se certificar totalmente de um e de outro desses tempos, mas é possível modulá-los numa temporalidade que vive da impossibilidade de domarmos o tempo, mas que nos conscientiza dessa impossibilidade. Para Ricoeur, é isso que fazem as narrativas, e a narrativa dos historiadores organiza o passado à medida que estes narram, que põem em intriga o que está na vida, fora do narrado. O historiador, 
para Ricoeur, como o ficcionista, elabora uma temporalidade terceira que não existe fora do narrado:

Tempo e narrativa se constituem reciprocamente: o tempo vivido é o objeto da narrativa, e a narrativa é a consciência de si possível do vivido. Enquanto seu objeto, o tempo vivido oferece as condições para a sua narrativa; enquanto consciência do vivido, a narrativa sai dele e retorna a ele, transformando-o. (Reis, 2005, p. 102).

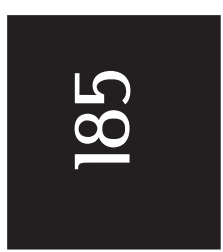

O que deveriam fazer os historiadores senão lidar com o tempo, o tempo passado, que de alguma forma deve ser transmitido? Vê-se que, para Ricoeur, o texto do historiador é também seu leit motiv: o que faz textualmente com os dados de sua investigação, e não em sua investigação mesma, apenas. A pesquisa ajuda-nos a rever teorias, testar suas validades, historicizando-as; mas se não fazemos aos documentos outras perguntas informadas pela teoria, a prática da pesquisa pode repetir as mesmas respostas, sempre.

A ênfase do papel do historiador como um oficial de arquivos tem fortes defensores, e, provavelmente, o principal desdobramento dela é o que assegura que a história deve ser indicial, conter provas sobre o passado. Aí, a verdade é possível sim, à medida que os historiadores podem dizer enunciados diversos conforme as fontes que nos informam de dados da realidade que possibilitam construir outras histórias, possíveis porque uma outra construção depende muito mais das informações verificáveis do que da trama textual. À semelhança do detetive que encontra vestígios do crime que podem mudar completamente a versão dos fatos. Não vamos resenhar aqui esse debate, mas importa-nos passar brevemente sobre o que Ginzburg (2002) tem a nos dizer sobre isso, certo que o autor é de que a postura metodológica de investigação das fontes é a principal tarefa da atividade historiadora.

Tomamos, com o autor, a definição que fez Aristóteles na Arte Retórica sobre a Retórica: "faculdade de ver teoricamente o 
Textos de ficção e tradição cientificista ficções da cultura histórica

que, em cada caso, pode ser capaz de gerar a persuasão" e não a persuasão mesma. Ginzburg critica a tradição de análise que separou retórica de prova em Aristóteles. Sigamos Aristóteles. Para ele, três são as espécies de prova que os discursos fornecem: as que residem ou no orador, ou no ouvinte e, por fim, as que são do próprio discurso. Todas essas provas são resultado de uma relação que se estabelece entre autor/escritor-leitor/ouvinte mediadas pelos textos. Mas é sempre uma relação que provoca ação, que depende de fatores textuais e contextuais. E aqui está uma suposição deste trabalho: o que fazem os historiadores senão textos? Ginzburg demonstra que o argumento dos narrativistas peca por tomar o texto aristotélico por algo que ele não faz, qual seja: afirmar que a retórica não depende de provas, e que é apenas jogos de linguagem, discursos. Não vamos discutir com Ginzburg o que é o próprio Aristóteles que enuncia: que uma das provas é o próprio discurso, suas qualidades e atributos persuasivos. Existe, a nosso ver, algo que escapa da contextualização pura, ou existe algo no texto que, se relacionando fora dele, nem por isso deixa de colaborar para que o contexto se organize de uma forma e não de outra.

Um dia, no século XIX, cientistas da história dessa tradição histórica que vamos debatendo aqui, puderam acreditar que seus textos iam além, porque eram o correlato verbal-discursivo da construção de unidades nacionais. Por seus textos, viam a afirmação de seus gestos textuais produzindo resultados concretos na vida ao reconstituir o passado para, no presente, apontar o futuro de toda uma comunidade. Fazendo assim, o que faziam os cientistas da História de então senão articular em discurso compreensível, argumentativo ou narrativo, uma história que não é senão uma estória? Sendo um trabalho de História, este aqui não poderia adotar automaticamente a equivalência entre o texto do historiador com o do escritor literário. Mas é nosso dever investigar o que, na divisão entre História e Literatura, história e ficção, do século XIX, a tradição cientificista anti-retórica praticou, avaliando se muito do que foi 
jogado fora não foi o bebê, acreditando que se jogava fora somente a água do banho. Carece de pegar o bebê de volta.

À exceção da tradição annaliste que gira em torno de uma teoria de abordagem do material histórico passado, a tradição metodológica francesa é ateórica. Ateórica porque, mesmo admitindo o caráter construído da história pela via do texto historiador, reitera, porém, a condição de ciência que deve se manter fiel a uma idéia de aceder ao real pelos documentos de arquivo, e a discussão do texto historiador cai para segundo plano. Muito da discussão teórica que se faz na História se recupera pela retomada da importância de se debater o texto do historiador e não se limitar ao aspecto técnico da investigação em arquivos. A tradição dita desconstrucionista, pós-moderna, pondera que as verdades sobre o real são sempre construções que dizem respeito ao caráter de operação de linguagem que pratica sobre a realidade daquele que a analisa. Aqui, advogamos uma verdade de meio-termo, e postulamos a idéia de que ninguém, nem o historiador mais metodológico, escapa dos processos de linguagem e transmissão ao conformar em texto a realidade que encontrou nos dados de sua pesquisa.

Isso não quer dizer que nos basta conhecer a linguagem e a retórica. Concordamos com Costa Lima ao afirmar que "não se entende a linguagem quando só se entende da linguagem" (Costa Lima, 2006, p. 409). Assim: não se entende a linguagem historiadora se só entendemos da linguagem. Apostando que é, no final das contas, disso o que tratam os narrativistas, limitando a história ao discurso, os anti-narrativistas entendem que com esse procedimento nunca estabeleceremos verdade alguma, porque a linguagem e seus processos são imponderáveis. Ou que a verdade sempre seria relativa àquele que fala, e do lugar de onde fala. Estamos mais com Ricoeur, com quem entendemos que se trata mesmo de uma aporia. Acreditamos que o relativismo e a verdade sobre as coisas não estão de fato nas coisas mesmas, mas muito mais faz parte de um acordo, e acordo político-moral, em torno do que julgamos certo ou errado sobre os 
Textos de ficção e tradição cientificista ficções da cultura histórica

acontecimentos. Ricoeur assegura que todo fato histórico está preso a um feixe de relações valorativas do historiador, nunca existindo em si mesmo, e é assim que compreendemos também.

Dizer que o Holocausto não tenha existido e que o massacre dos judeus seja uma invenção, é uma coisa; outra é dizer que as premissas de que partem revisionistas e historiadores comprometidos com a verdade são diferentes. Porque, de fato e de juízo, ninguém duvida de que campos de concentração tenham existido, mas alguns querem fazer acreditar que eles existiram numa certa conformação de motivações que dá aos fatos estarrecedores do tratamento dos judeus em campos de concentração alemã na Segunda Guerra uma feição sem crueldade. Ora, aí está a questão da verdade, que não está dada no documento, mas no juízo que fazemos sobre os fatos: não só é inadmissível se aceitar o que aconteceu, como aceitar que se fale que o que aconteceu tenha sido diferente do que aconteceu em se tratando do Holocausto! Trata-se aí de algo que afronta de tal forma o acordo sobre a desumanidade e a estupidez dos atos contra os judeus, que não aceitamos de forma nenhuma que seja dita qualquer outra coisa que não se pareça com a estupidez humana sujeita a reparo e expiação. Para tudo isso, a escola metodológica que nos ensinou a identificar e a combater a falsificação é crucial: os documentos revelam, não deixam margem a dúvidas sobre a existência dos fatos, mas o juízo sobre eles não é o documento que faz, mas os homens historiadores de um e de outro campo dessa discórdia.

O Holocausto é tão ignominioso que nem conseguimos discutir com quem quer que seja que avente a possibilidade de que ele não existiu. Se seguimos o raciocínio de Ricoeur sobre a configuração dos fatos em torno das histórias que os organizam em sentidos, coisa que por outra via White também faz, um certo holocausto não existiu mesmo não. Mas não é disso que se trata: trata-se de que é um acinte o fato de partilhar de outra moral que não seja a de reprimir e rejeitar peremptoriamente algo parecido com o Holocausto! Poderíamos passar um dia inteiro se lembrássemos das guerras, o 
11 de setembro, atentados terroristas de toda sorte, chacinas, invasões militares de território, calabouços ditatoriais etc., etc., etc., e que não faríamos muito esforço para encontrar em nossa realidade brasileira. É preciso separar-se novamente da mesma tradição de que estamos tratando aqui, retirando dela o que pode nos servir, e recusando o que já não se sustenta. Os documentos que o historiador pesquisa não revelam, em si, a verdade das coisas, da qual o historiador metódico e consciencioso no trato com as fontes é o revelador, conforme a tradição cientificista.

Não, não: o historiador - e não diferente de muitos outros homens que não são historiadores - é o sujeito que tem uma responsabilidade que as sociedades lhe atribuem, de fazer exatamente isso que estamos questionando aqui: revelar a verdade. A esse chamado o historiador deve atender, e zelar pelos acordos em torno dos quais verdades se estabelecem. Mas o historiador deve revelar também que sua verdade é parcial, social, não de caráter divino de quem "revela"; que sua verdade é construída segundo valores, crenças e juízos, e que ele organiza, seleciona, "esquece" documentos que não sejam conforme o que quer pleitear sobre a verdade e o certo sobre as coisas, e imagina, preenche vazios, conferindo sentido ao que é alheio aos fatos mesmos.

O historiador deve buscar permanentemente outros fatos, e também deve avaliar com mais vagar o que é ficcional, para que entenda, de vez, que certas realidades, certos aspectos que são do mundo dos valores, das crenças, dos juízos estão mais bem elaborados, sugeridos e organizados nos textos-documentos literários que são realizados sem a injunção de ter de verificar correspondência entre o que se diz e do que se diz: entre a palavra e a coisa, para pensar com Foucault. Certamente há referencialidade, e entendemos aqui que, quando não temos a obrigação de dizer verdades, muitas vezes são exatamente os momentos em que elas mais vêm à tona. "Ah, como verificar isso?" perguntaria alguém. Entendemos que essa pergunta é necessária apenas pela metade: o importante é verificar se as verdades têm aderência, se são tomadas como verdade e qual é o acordo em torno da qual se faz. 
Textos de ficção e tradição cientificista ficções da cultura histórica

Afinal, os historiadores, ao fazerem textos, esses também são recepcionados.

Porém, é fundamental seguir as advertências que fazem historiadores como Chartier, que, pela história da leitura, estuda as manipulações, injunções e pressões sociais de poder e de interesses em torno das quais os acordos de verdade, e os textos pelos quais se organizam, são construídos. E, uma vez mais, trata-se de desmistificar uma versão sobre o historiador de revelador de verdades inscritas no documento, lastreadas pela tradição cientificista da História. Nesse sentido, faz muito bem De Certeau quando afirma que a ciência é uma igreja, para que todos possam saber que as verdades da História são verdades construídas segundo jogos de interesses e de poder que os discursos sobre a verdade das coisas organizam. Isso tudo talvez fizesse muito bem a muitos de nós, historiadores, para que retiremos de nossas costas aquilo que White chama de um "fardo". A sociedade está, quase sempre, a exigir da História uma capacidade que ela não tem: a de dizer verdades. A cultura histórica extramuros acadêmicos parece-nos muito crente dessa capacidade de o historiador revelar verdades que o século XIX forjou.

\section{Finalmente, João Guimarães Rosa}

E, afinal, como a literatura de Guimarães Rosa se articula em relação a essa tradição que estamos discutindo e ponderando aqui? Ao que alguma coisa já nos indica, o escritor joga com essa tradição que articula História e Literatura por sua separação, reforçando o próprio de seu literário, porém lançando mão do próprio do histórico. Embora tenha renovado profundamente a literatura brasileira, Rosa a renovava utilizando-se da tradição separatista de relação da história com a literatura, profundamente enraizada na cultura histórica, e que vínhamos analisando até aqui. Essa tradição encharca nossa cultura histórica separando real de ficcional, 
história-documento de literatura-invenção, fato de fantasia, criação imaginada e criação controlada, como se a literatura também não fosse controlada, não recebesse do mundo injunções e constrangimentos.

Guimarães Rosa faz um jogo com essa tradição a fim de colocá-la a seu favor. Porque Guimarães Rosa punha marcas de história em seus textos, convocando para eles a autoridade que os documentos da História, os documentos do passado conferem a tudo que se diz. Como escritor de literatura, e para continuar alimentando as incertezas de veracidade do que é próprio do literário, Rosa ia cuidando para não ultrapassar o limite a partir do qual pudessem ser aquelas marcas de história em seu texto tomadas como verificação e atestação de realidades existentes de fato. Quando seu livro Corpo de Baile se publicava na Alemanha, o tradutor quis inserir na abertura de uma das novelas um rodapé para explicar uma das epígrafes, uma quadrinha de uma cantiga ouvida no sertão, esclarecendo ao leitor alemão do que se tratava. Depois de alguma discussão, o escritor fechou assunto: não aceitava aquilo porque seu livro não era "documento histórico". Talvez a mais célebre chave de leitura de seus textos com que Rosa quis marcar a distância de sua ficção com a história esteja na primeira linha de um dos quatro prefácios do livro Tutaméia: "A estória não quer ser história. A estória, em rigor, deve ser contra a História [...]".

Grande Sertão: Veredas está marcado pelo procedimento de se autorizar o relato do passado pela utilização de documentos. Começa que o próprio Riobaldo Tatarana é um grande documentomonumento que está à frente do "senhor" que ouve e anota o relato do jagunço para depois transformá-lo em livro. Riobaldo é testemunho da história brasileira. $\mathrm{O}$ autor sabe que Riobaldo não é apenas um personagem do seu livro, mas também a condição suprema da autoridade de tudo que vai escrever, autorizado pela condição de velho contador de estória e documento da história. $\mathrm{O}$ homem que ouve Riobaldo e o jagunço mantém uma relação de 
Textos de ficção e tradição cientificista ficções da cultura histórica

mútua autorização: sem a autoridade de um, a do outro não vive! $\mathrm{E}$ ambos não podem viver sem a autoridade que os documentos da História conferem àqueles que os convocam. O livro pode dizer até mesmo o que não existiu como se tivesse existido. $\mathrm{O}$ livro bebe de outros documentos para conferir verdade ao relato. Está em jogo aí um procedimento que aproxima os territórios das estórias e da História pela simulação de afastamento delas, porque Rosa está inscrito na tradição que coloca estórias e História em contraponto, em terrenos separados, essa tradição de que estamos falando até agora. E, claro, se aproveita dessa separação para conferir ao próprio relato a veracidade que a autoridade dos documentos velhos confere ao passado, sem deixar perceber que o que diz possa ser historicamente existente fora do texto.

No jogo de mútua autorização entre personagem e autor do livro, o livro assinala documentos históricos no corpo do relato. ${ }^{2} \mathrm{~A}$ certa altura, Riobaldo conta o encontro com "um velho homem"; na passagem pela fazenda de Seo Habão, no retiro Valado, Riobaldo assinala que encontrou "consoante o diploma de patente, que no chão, num canto, avistei, lavrado preenchido cerimonial, de que esse Habão era Capitão da Guarda Nacional, em válidos títulos”. Durante encontro com homens do povoado do Sucruiu, a quem Zé Bebelo não maltrata, um homem dele se aproxima com uma nota de dinheiro: "era um dobrão de prata, antigo do Imperador, desses de novecentos-e-sessenta réis em cunho, mas que na Januária eles dão dois mil réis". Num dos momentos mais tensos do romance, quando os jagunços de Riobaldo estão cercados na fazenda dos Tucanos pelos homens de Hermógenes, Zé Bebelo chama Riobaldo, jagunço que sabe ler e escrever, para escrever bilhetes que serão levados a soldados do governo com quem Zé Bebelo tinha relações para virem surpreender os adversários pelas costas e livrá-los do cerco. Riobaldo pede que alguém encontre dentro da casa algum papel:

Anos 90, Porto Alegre, v. 14, n. 25, p.175-197, jul. 2007 


\section{Bruno Flávio Lontra Fagundes}

advindo que algum me trouxe mais papel, achado por ali, nos quartos em remexidas gavetas. Só coisa escrita já, de tinta firme; mas a gente podendo aproveitar o espaço em baixo, ou a banda de trás, reverso dita. Que era que estava escrito em papéis tão velhos? Um favor de carta, de tempos idos, num vigente fevereiro, 11 , quando ainda se tinha imperador, no nome dele com respeito se falava. E noticiando chegada em poder, de remessa de ferramenta, remédios, algodão trançado tinto. A fatura com negócios de escravos, compra, os recibos, por Nicolau Serapião da Rocha. Outras cartas...

E, no final do livro, Riobaldo revela sua última ação antes de se despedir da jagunçagem: buscar a certidão de batismo de Diadorim, certidão de que o livro se serve para selar sua própria autoridade pela via de documentos da História - as certidões guardadas em velhos arquivos, que conferem veracidade ao seu relato. Os arcaísmos, os modos de dizer remanescentes de formas de expressão que se mantêm nas práticas oralizadas de memória, são tanto criações do universo da "língua de Rosa" como registros de permanente pesquisa.

O Grande Sertão: Veredas, e muito da obra de Rosa, podem ser lidos como um grande glossário, ou um inventário, como esses livros de memória que desenham homens gloriosos, valorizam a geografia de rios, ribeirões e serras, riscam o traço pitoresco da sua gente, registrando antropônimos e topônimos inteiros, muitos dessas fontes de que os historiadores muitas vezes lançam mão. Mas como? Documentos de História em livros de Literatura? Sim, porque o que importa é exatamente o como se, próprio do ficcional. Vivendo da autoridade de verdade que uma certa tradição confere a tudo aquilo que se diz com base em documentos, o escritor pode inventar, reforçando mais ainda a baliza de que o ficcional é o que transtorna, porque às vezes se parece com aquilo que se asseme-lha a seu avesso: o real. Se não sabemos se o livro de Rosa diz de realidades ou não, 
Textos de ficção e tradição cientificista ficções da cultura histórica

acreditamos que o que está ali pode ser o relato sobre uma realidade existente numa época histórica a que recusamos veracidade, muito menos pelo que ele nos diz e mais pelo que vem sabido para nós como literário, "livro de literatura", muitas vezes posto na capa do livro.

Será à toa que a natureza na literatura roseana seja contemplação e deleite? Ali, a natureza é um quase-cenário, cujo encanto penetra o irracionalismo e a lógica maravilhosa dos personagens. A natureza não é hostil ao homem, não há conflitos de raças, os sertanejos não são pobres e vítimas de desigualdades, os sertanejos sem escola e sem letra convivem com os homens de letra e com a letra escrita. Na natureza da literatura de Rosa, todos cantam, fazem sons ou música: os homens, os bichos, os riachos, as árvores, as palavras. Quadro tão inusitado, tematizado pela primeira vez na literatura brasileira, não podemos ver aí ressonâncias de um diálogo surdo com tradições da história do pensamento social brasileiro que tematizaram as raças, a natureza e a sociedade de forma tão diversa? Se aceitamos que a literatura também fala a realidade, mais uma vez Rosa sabia que não podia se parecer com o que a tradição do pensamento brasileiro havia dito, senão sua literatura seria história, documento. Mas o "universo lingüístico-literário" de Rosa, não temos dúvida, é tanto invenção e trabalho da escrita como registros de pesquisa nas poucas viagens feitas ao sertão ou recolhidas por seus correspondentes lá.

Rosa joga com essa tradição separatista entre História e Literatura para que seja lido, consumido como alguém que escreve uma literatura que é pura metafísica, estórias do sertão, tomado como espaço geográfico mas também universo existencial de criação. Nada mais próximo do literário, que não precisa firmar-se na validade e na verificabilidade do que diz. O escritor faz uma espécie de glosa dessa tradição, rejeitando a história como documento mas se utilizando de marcas de passado que conferem autoridade a seus textos, aliando história com literatura sem quebrar o estatuto de ficcionalidade 
do literário. Ele está dentro da longa tradição na nossa cultura histórica que separa rigidamente história e ficção e se utiliza dela para torná-la uma coisa ambivalente, porque ao mesmo tempo real e ficcional, fato e fantasia, invenção e registro, documento e não-documento.

Hoje, essa tradição separatista perde força, e questionamos se qualquer literatura não é mesmo um documento, mas um documento que não é mais aquele que equaciona documento com verdade. A literatura de Guimarães Rosa elabora algo ficcionalmente para nos dizer uma verdade: que há uma tradição que vem há tanto tempo insistindo em não discutir a natureza narrativa da história, o que reforçou ilusões na cultura histórica. Os historiadores revisam hoje essa longa tradição que tanto marcou sua cultura histórica durante tanto tempo, e que parece fortemente ainda arraigada no seio da cultura histórico-social. A literatura de Rosa parece ajudar-nos a espantar esse fantasma, a discutir essa tradição. Que existem relações entre Literatura e História, entre ficção e realidade, entre texto do historiador e do escritor literário, parece não haver dúvidas. Quais são elas mais precisamente é que cabe se perguntar.

Fiction and cientificist tradition texts - fictions of historical culture

Abstract. This article points out to some dilemmas and challenges posed to historians' work, nowadays, by the long historical scientificist tradition inherited from the XIXth Century, which put Literature and History in disciplinary fields completely distinct. Through the analysis of Guimarães Rosa's procedures of literary composition and creation in his book Grande Sertão: Veredas, this article tries to discuss the value of literary texts helpful to historians to overcome those dilemmas and challenges.

Keywords: Historical tradition. Historical Knowledge. Literature.

\section{Notas}

${ }^{1}$ Este texto é versão modificada de trabalho final da disciplina História da Teoria da História Contemporânea: da "metanarrativa" (Hegel) à "História Repensada" (Jenkins), apresentado no segundo semestre de 2006 no Departamento de História 
Textos de ficção e tradição cientificista ficções da cultura histórica

da UFMG, onde desenvolvo pesquisa de doutorado sobre a literatura de João Guimarães Rosa e a Livraria José Olympio Editora, para o que, como bolsista, conto com o apoio da Fundação de Amparo à Pesquisa do Estado de Minas Gerais (FAPEMIG).

${ }^{2}$ Os trechos a seguir, em aspas, foram retirados de Grande Sertão: Veredas, quinta edição, 1967. Não fizemos referência ao número da página porque isso é indiferente aos argumentos que expusemos neste artigo.

\section{Referências}

ARAUJO, Ricardo Benzaquen. História e Narrativa. Revista do Departamento de História. FAFICH-UFMG. Anais do Seminário Fronteiras na História, jul. 1992, p. 57-75.

ARISTÓTELES. Arte Retórica e Arte Poética. São Paulo: Difusão Européia do Livro, 1959. p. 331.

BOMENY, Helena. Encontro Suspeito: História e Ficção. Revista Dados de Ciências Sociais. Rio de Janeiro, v. 33, n. 1, 1990, p. 83-118.

CHARTIER, Roger. A história entre narrativa e acontecimento. In: À beira da falésia. A História entre certezas e inquietudes. Porto Alegre: Ed. da Universidade UFRGS, 2002. p. 81-100.

. Figuras retóricas e representações históricas. In: .p. 101-116.

COSTA LIMA, Luiz. A narrativa na escrita da história e da ficção. In: A aguarrás do tempo. Estudos sobre a narrativa. Rio de Janeiro: Rocco, 1989, p. 15-122.

Perguntar-se pela escrita da história. Varia Historia. Programa de PósGraduação História UFMG, v. 22, n. 36, jul./dez. 2006, p. 395-422.

DE CERTEAU, Michel. Fazer História. In: . A Escrita da História. 1 ed. Rio de Janeiro: Forense Universitária, 1982a, p. 31-64.

. A operação historiográfica. In: . 1982b, p. 65-119.

FOUCAULT, Michel. A arqueologia do saber. 5 ed. Rio de Janeiro: Forense Universitária, 1997, p. 192.

GINZBURG, Carlo. Relações de força. História, retórica, prova. São Paulo: Cia das Letras, 2002, p. 192.

ISER, Wolfgang. Atos de fingir. In: O fictício e o imaginário. Perspectivas de uma antropologia literária. Rio de Janeiro: Ed. UERJ, 1996. p. 13-38.

Anos 90, Porto Alegre, v. 14, n. 25, p.175-197, jul. 2007 


\section{Bruno Flávio Lontra Fagundes}

JENKINS, Keith. A história repensada. São Paulo: Contexto, 2001, p. 117.

JUNIOR, Helio Rebello Cardoso. Enredos de Clio - Pensar e escrever a história com Paul Veyne. São Paulo: Ed.UNESP, 2003, p. 214.

NIETZSCHE, F. Segunda Consideração Intempestiva: da utilidade e desvantagem da História para a Vida. Rio de Janeiro: Relume Dumará, 2003.

REIS, José Carlos. Teoria e História da "Ciência Histórica”: tempo e narrativa em Paul Ricoeur. In: FIGUEIREDO, Betânia Gonçalves; CONDÉ, Mauro Lúcio Leitão. Ciência, História e Teoria. Belo Horizonte: Argumentum, 2005, p. 93-122.

RICOEUR, Paul. A história e a narrativa. In: . Tempo e narrativa. Tomo I. São Paulo: Papirus, 1994. p. 133-326.

STARLING, Heloiza. Lembranças do Brasil. Teoria Política, História e Ficção em Grande Sertão: Veredas. Rio de Janeiro: Editora Revan; Iuperj,Ucam, 1999, p. 192.

WHITE, Hayden. O texto histórico como artefato literário. In: Trópicos do discurso. Ensaios sobre a crítica da cultura. São Paulo: EDUSP, 1994a, p. 97-116.

. O fardo da História. In: 1994b, p. 39-64.

Recebido em 28/03/2007

Aprovado em 04/07/2007

Anos 90, Porto Alegre, v. 14, n. 25, p.175-197, jul. 2007 